\title{
Muhammadiyah dan Al-Washliyah di Sumatera Utara; Sejarah, Ideologi, dan Amal Usahanya
}

\author{
Ali Marzuki Zebua \\ Institut Agama Islam Negeri (LAIN) Kerinci \\ e-mail: alimarzukizebua@,iainkerinci.ac.id
}

\begin{abstract}
Minangkabau and Mandailing are two different ethnicities. Minangkabau ethnicity has a modernist dominant Muslim and has a matrilineal tradition. While the Mandailing ethnic group has a conservative dominant Islam and has a patrilinear tradition. Of the two ethnic groups, two large organizations were born on the island of Sumatra, namely Mubammadiyah from the Minangkabau ethnic group identified with Pemuda and AlWashliyah from the Mandailing ethnic group identified with Kaum Tua, both of which had major influences in education, culture and health and politics. . In this case, it is necessary to see how history, ideology, and charitable endeavors from these two large organizations influence change at the local and national scale.
\end{abstract}

\section{Keywords: Muhammadiyah, Al-Washliyah, History, Ideology, Charity Business.}

ABSTRAK. Minangkabau dan Mandailing adalah dua etnis yang berbeda. Etnis Minangkabau memiliki pemeluk Islam yang dominan modernis serta memiliki tradisi matrilinear. Sedangkan etnis Mandailing memiliki pemeluk Islam yang dominan konservatif serta memiliki tradisi patrilinear. Dari dua etnis ini terlahir dua oragnisasi besar di pulau Sumatera,yakni Muhammadiyah dari etnis Minangkabau yang diidentikkan dengan Kaum Muda dan Al-Washliyah dari etnis Mandailing yang diidentikkan dengan Kaum Tua, yang keduanya memiliki pengaruh besar baik di bidang pendidikan, kebudayaan maupun bidang kesehatan dan politik. Terkait dengan hal ini kiranya perlu melihat bagaimana sejarah, ideologi dan amal usaha dari dua organisasi besar ini yang mempengaruhi perubahan pada skala lokal maupun Nasional.

Kata kunci: Muhammadiyah, Al-Washliyah, Sejarah, Ideologi, Amal Usaha. 


\section{PENDAHULUAN}

Walaupun negeri Minangkabau dan Mandailing bertetangga, namun kedua kelompok etnik ini sangat berbeda. Menurut Usman Pelly, kelompok etnis Minangkabau sebagian besar adalah pemeluk Islam modernis yang memiliki tradisi matrilinear yang kuat, terutama dalam hal suksesi, pewarisan, identitas, legitimasi, dan cenderung untuk merantau. Sementara itu, kelompok etnis Mandailing sebagian besar dikenal sebagai muslim konservatif yang memiliki tradisi patrilinear yang kuat dalam hal suksesi, pewarisan, identitas, dan legitimasi serta lebih cenderung untuk melakukan perluasan territorial (Al Rasyidin, dkk, 2011: 3). Dari dua etnis ini terlahir dua organisasi besar di pulau Sumatera, yakni Muhammadiyah dan Al-Washliyah.

Muhadjir Effendy menegaskan bahwa jati diri Muhammadiyah itu adalah gerakan (Movement). Jadi bukan organisasi. Kemudian kata gerakan itu di dalam anggaran dasarnya dijabarkan lebih lanjut sebagai "Gerakan dakwah amar makruf nahi munkar" (Muhadjir Effendy, 2005: iii).Gerakan ini di dominasi oleh etnis Minangkabau dalam kepengurusan dan keanggotaannya.Kenyataan ini semakin lama memperkuat pengaruh etnis Minangkabau di Sumatera Timur. Karenanya, etnis Mandailing merasa eksistensi mereka terusik dan terancam oleh ekspansi sekolah-sekolah Muhammadiyah yang dibangun dan dikembangkan etnis Minangkabau di Sumatera Timur, baik di kota maupun di desa. Dalam kenyataannya, sekolahsekolah Muhammadiyah lebih disukai oleh anak-anak dan orang tua mereka ketimbang sekolahsekolah Melayu dan Mandailing. Setidaknya, hal itu dikarenakan manajemennya lebih teratur, memberi pelajaran umum dan agama, dan mempunyai kegiatan ekstrakurikuler seperti kepanduan dan perkemahan, mirip dengan sekolah-sekolah Belanda. Kebanyakan guru sekolah Muhammadiyah berasal dari Minangkabau dan merupakan lulusan dari sekolah Islam modern, misalnya Sumatera Thawalib dan Diniah Putri. Mereka mengorganisir kaum wanita menjadi bagian khusus dari Muhammadiyah dengan nama Aisyiyah (nama isteri Nabi) dan membentuk Pemuda Muhammadiyah. Perantau minangkabau menawarkan fasilitas pendidikan mereka bukan hanya untuk perantau minang, melainkan juga kepada orang Melayu dan perantau Mandailing. Mereka mengajak kau wanita dan kaum muda untuk memasuki Muhammadiyah. Demikianlah orang Mandailing menghadapi tantangan dari gerakan Muhammadiyah yang kian hari semakin solid.

Melihat fakta di atas, penulis mencoba melihat dari sisi yang berbeda di tinjau dari segi sejarah, ideologi, dan amal usaha dari dua organisasi besar Islam yang berada di Sumatera Utara ini, yang hingga sekarang sama-sama berpengaruh terhadap pembangunan dan kemajuan Islam, khususnya di Sumatera Utara.

\section{A. MUHAMMADIYAH}

1. Sejarah Pembentukan Muhammadiyah di Sumut

Kapan Muhammadiyah masuk ke Sumatera Timur? Oleh Bapak Kalimin Sunar dalam makalahnya seperti yang penulis kutip buku Porfil Mubammadiyah Sumatera Utara dijelaskan bahwa pengesahan berdirnya Muhammadiyah di Sumatera Timur adalah tanggal 1 Juli 1928, namun kegiatan propaganda (dakwah) gerakan Muhammadiyah sudah dimulai sejak tanggal 25 Nopember 1927 pada sebuah tempat di Jalan Nagapatam Nomor 44 Kampung Keling, Medan. Tempat pertemuan itu kini sudah berubah nama menjadi Jalan Kediri. Rumah itu smpai kini masih ada, namun nampaknya dalam penguasaan orang lain.

Pada saat itu biasanya di sana berlangsung pengajian rutin. Tetapi kali ini berubah agenda menjadi rapat pembentukan organisasi Muhammadiyah. Pada tanggal 25 Nopember 1927 tersebut mulailah para perantau-perantau dari minangkabau yang sudah menetap di Sumatera Timur menghimpun kawan-kawan yang sepaham dengan 
Muhammadiyah, ditandai ketika muzakarah, dan yang shalat disekitar pajak (pekan) bundar (kini sudah dibongkar). Disanalah bertemu St. Juin, Mas Pono, Sutan Marajo, Kari Suib dan kawan-kawan lain dari Tapanuli, mereka sepakat mendirikan Muhammadiyah, yangmana awal dari gerakan ini sendiri dirintis sejak tahun 1923, terutama oleh Mas Pono. Maka didekatilah HR Muhammad Said, sebagai tenaga baru kekuatan Muhammadiyah (Profil Muhammadiyah Sumatera Utara, 2005: 4-5).

Pemimpin pertemuan pada saat itu adalah HR Mohammad Said. Ia seorang cendekiawan dan aktivis politik (Sarikat Islam Pematangsiantar). HR Mohammad Said wafat tanggal 22 Desember 1939. Dalam buku Karel A. SteenBrink (1986, 76) Hamka menceritakan perihal wafatnya tokoh besar ini dengan rinci. Tentang jumlah pelayat yang demikian besar, tentang pemberitaan media yang melukiskan perasaan kehilangan. Tetapi ada yang amat menarik, bahwa saat menyaksikan deraian air mata jama'ah yang menangisi kepergian almarhum HR Mohammad Said, dengan amat tegas HAMKA berkata: "Apa yang kita tangiskan tuan-tuan? Siapa yang kita tangisi? Padahal almarbum yang kita cintai ini wafat meninggalkan jasa yang amat besar. Kalau hendak. menangis juga, sebaiknya tangisilah diri sendiri karena tidak mempunyai jasa sebesar almarbum HR Mohammad Said”.Hr Mohammad Said juga dikenal sebagai pemimpin sebuah surat kabar (Pewarta Deli). Sebelum maupun sesudah pendirian Muhammadiyah Sumatera Timur (Sekarang Kota Medan, Sumut), beliau sudah kerap mewartakan organisasi ini kepada pembacanya.

Jika terdapat jama'ah yang berbilang, tentulah pengurus Muhammadiyah yang diputuskan saat itu tak cuma belasan orang: Hr Mohammad Said (Ketua), Djuin St Penghulu (Wakil), Maspono (Sekreraris), Pangulu Manan (Wakil), dan seorang advisor bernama Tandjung Moehammad Arief. Selain itu kepengurusan dilengkapi 5 anggota: Kongo St Maradjo, Hasan St Batuah, Awan St Saripado, H Su'ip, dan Sutan Berahim.Sebagian besar anggota pimpinan Muhammadiyah berasal dari Minangkabau, walaupun ada juga beberapa orang berasal dari Jawa dan Melayu. Dari sebelas anggota pimpinan, enam orang bergelar Sutan dan boleh diaggap sebagai orang yang berasal dari Sumatera Barat. Tidak seorangpun yang memakai nama Batak (Karel A. Steen Brink, 1986: 77).

Mengembangkan sayap pada masa sulit, HR Mohammad Said memimpin pengembangan Muhammadiyah dengan titik awal di sebuah kota terpenting (Medan). Frekuensi gerakan dakwah Muhammadiyah semakin ditingkatkan, dengan mendatangkan penceramah dari Sumatera Barat dan penceramah lainnya, yang terfokus pada masalah usholli, meluruskan arah kiblat, shalat pakai dasi, kenduri kematian, ziarah kubur (kuburan keramat), shalat Hari Raya dilapangan terbuka dan shalat lain 11 rakaat, terutama bulan ramadhan. Setelah itu tercatatlah pertumbuhan cukup menggembirakan di berbagai kota dan pelosok lainnya. Kegiatan Muhammadiyah di Medan sama seperti di tempat lain yaitu: tabligh, mendirikan sekolah dengan memakai sistem gubernemen, membentuk organisasi wanita, kepanduan dan lain sebagainya (Pijper: 166-167).

2. Ideologi Muhammadiyah

Muhammadiyah dalam memahami dan mengamalkan Islam berdasarkan al-Qur'an dan Sunnah Rasul dengan menggunakan akal pikiran sesuai ajaran Islam. Pengertian alQur'an sebagai sumber ajaran Islam adalah kitab Allah yang diwahyukan kepada Nabi Muhammad Saw. sedangkan sunnah Rasul adalah sumber ajaran Islam beruapa penjelasan dan pelaksanaan ajaran-ajaran dalam al-Qur'an yang diberikan oleh Nabi Muhammad Saw. (matan keyakinan dan cita-cita hidup Muhammadiyah) (Musthafa Kamal Pasha dan Ahmad Adaby Darban, 2003: 43). 
Bagi Muhammadiyah, memahami Islam secara benar sangatlah menentukan beragama secara benar pula. Apabila faham tentang Islam itu tidak benar maka tidak akan benar menangkap hakekat dan citra ajaran Islam secara benar. Sehingga akan berpengaruh terhadap pengamalannya dalam kehidupan secara benar pula. Oleh karena itu, untuk memahami Islam perlu dasar yang kokoh dan benar.

Sebagai gerakan Islam modern, Muhammadiyah dalam membersihkan Islam dari pengaruh ajaran yang salah mendasarkan programnya terhadap sistem pendidikan Islam, dan memperbaiki kondisi sosial kaum muslimin Indonesia pada saat itu. Diantara program-program ini maka pendidikan merupakan aspek yang sangat menonjol dari pembaharuan yang dilakukan Muhammadiyah pada saat itu. Sebagai gerakan yang berlandaskan agama, maka ide pembaharuan Muhammadiyah ditekankan pada usaha untuk memurnikan Islam dari pengaruh tradisi dan kepercayaan lokal yang bertentangan dengan ajaran Islam.

Ideologi Muhammadiyah sendiri adalah sistem keyakinan, cita-cita dan arah perjuangan. Tujuannya adalah untuk terbentuknya perilaku individu dan kolektif seluruh anggota Muhammadiyah yang menunjukkan keteladanan yang baik (uswah hasanab) menuju terwujudnya Masyarakat Islam yang sebenar-benarnya (Ahmad Mansur Surya Negara, 1996: 220). Batang tubuh Muhammadiyah adalah;(1) Muqaddimah anggaran dasar Muhammadiyah. (2) Kepribadian Muhammadiyah. (3) Keyakinan dan cita-cita hidup Muhammadiyah. (4) Pedoman hidup Islami warga Muhammadiyah. (5) Keputusankeputusan Resmi Muhammadiyah. Ideologi Muhammadiyah merupakan wujud pembinaan kualitas iman menuju ketaqwaan, karena dengan ungkapan lain religiousspirituality yang tepat akan mempengaruhi segala bentuk dan langkah seseorang, dan pada gilirannya berpengaruh pada kerja keras, kerja cerdas, serta kerja ikhlas dalam suatu organisasi (Ari Anshori, 2000).

3. Amal Sholeh dan Amal Usaha Muhammadiyah

Tidaklah berkelebihan kalau dikatakan bahwa perserikatan Muhammadiyah adalah satu organisasi sosial masyarakat Islam Modern yang terbesar di seluruh Dunia Islam. Muhammadiyah dengan tambahan ya' nisbah, Muhammad ditambah ya' yang menunjukkan jenis, artinya Mengambil suri tauladan terbaik dari nabi Muhammad SAW. Dalam upaya menjadi pemimpin: (1) al Amin, (2) dalam berbisnis dan bewirausaha, (3) dalam kehidupan rumah tangga, (4) dalam berdakwah, (5) dalam menata tatanan sosial dan politik, (6) dalam menata sistem hukum, (7) system pendidikan dan (8) strategi perjuangan militer. Bahkan pada masa kini terdapat tuntutan (9) menata arus informasi dalam era global. Dalam kaitan ini usaha-usaha yang dilakukan Muhammadiyah banyak terkait dengan masalah-masalah praktis ubudiyah dan muamalah.

Disamping itu, tidak dapat disangkal bahwa keberhasilan kiprah usaha-usaha Muhammadiyah dibidang pendidikan dan pelayanan sosial kepada masyarakat sangat besar, kalau tidak hendak dikatakan luar biasa (M.A Fattah Santosa\& Maryadi, 2001: 3). Seiring dengan usianya yang bertambah, Muhammadiyah Sumut sudah melahirkan berbagai amal usaha, baik dalam bidang Pendidikan (TK hingga Perguruan Tinggi)seperti UMSU yang didirikan pada 29 Februari 1957) atas prakarsa HM Bustami Ibrahim, dkk. UMSU kemudian memperkarsai berdirinya Universitas Tapanuli Selatan (1984), Sekolah Tinggi Ekonomi dan Sekolah Tinggi Ilmu Hukum di Kisaran-Asahan., Kesehatan (RS Muhammadiyah/Aisyiyah); salah satunya RS Muhammadiyah Jl. Mandala By Pass, Medan yang hingga kini masih eksis, dan berbagai amal usaha lainnya yang tidak sedikit jumlahnya.

Secara garis besar, amalan-amalan Soleh dalam Muhammadiyah di antaranya dirumuskan dalam amal usaha, yang diwujudkan dalam bentuk amal usaha, program, dan kegiatannya yakni meliputi: 
1) Menanamkan keyakinan, memperdalam dan memperluas pemahaman, meningkatkan pengamalan, serta menyebarluaskan ajaran Islam dalam berbagai aspek kehidupan.

2) Memperdalam dan mengembangkan pengkajian ajaran Islam dalam berbagai aspek kehidupan untuk kemurnian dan kebenaran.

3) Meningkatkan semangat ibadah, jihad, zakat, infak, wakaf, shadaqah, hibah, dan amal sholeh lainnya.

4) Meningkatkan harkat, martabat dan kualitas sumber daya manusia agar berkemampuan tinggi serta berakhlak mulia.

5) Memajukan dan memperbaharui pendidikan dan kebudayaan, mengembangkan ilmu pengetahuan, teknologi, dan seni serta meningkatkan penelitian.

6) Memajukan perekonomian dan kewirausahaan kearah perbaikan hidup yang berkualitas.

7) Meningkatkan kualitas kesehatan dan kesejahteraan masyarakat.

8) Memelihara, mengembangkan dan mendayagunakan sumberdaya alam dan lingkungan untuk kesejahteraan.

9) Mengembangkan komunikasi, ukhuwah dan kerjasama dalam berbagai bidang dan kalangan masyarakat dalam dan luar negeri.

10) Memelihara keutuhan bangsa serta berperan aktif dalam kehidupan berbangsa dan bernegara.

11) Membina dan meningkatkan kualitas serta kuantitas anggota sebagai pelaku gerakan.

12) Mengembangkan sarana, prasarana dan sumber dana untuk mensukseskan gerakan.

13) Mengupayakan penegakan hukum, keadilan, dan kebenaran serta meningkatkan pembelaan terhadap masyarakat.

14) Usaha-usaha lain yang sesuai dengan maksud dan tujuan Muhammadiyah. (Lihat Anggaran Rumah Tangga Muhammadiyah, Pasal 3 mengenai Usaha).

\section{B. Al - JAM'IYATUL WASHLIYAH}

1. Sejarah Awal Lahirnya Al - Jam’iyatul Washliyah

Sejarah awal berdirinya Al Washliyah sangat erat sekali dengan awal perkembangan dari situasi dan kondisi yang ada di Sumatera Utara (yang dahulu disebut Sumatera Timur). Di mana Sumatera Timur merupakan wilayah kesultanan yang seiring dibukanya perkebunan besar, daerah ini kemudian menjadi terkenal walaupun hal ini menyebabkan semakin dikuranginya kekuasaan para sultan oleh penguasa Belanda yang pada akhirnya wewenang kesultanan itu hanya terbatas pada bidang keagamaan saja. Sehingga daerah ini menjadi migrasi dengan penduduk yang multi etnis (Chalijah Hasanuddin, 1988: 34-35).

Dalam hal pendidikan keIslaman yang ada di Sumatera Timur saat itu masih bersifat tradisional, yang lebih dikenal dengan pengaiian. Di Sumatera Timur sama dengan di beberapa daerah yang lain di Indonesia, pengajian itu dilakukan oleh anak yang mulai umur 6-12 tahun, selain itu mereka pada usia ini biasanya belajar di sekolah tingkat dasar (Chalijah Hasanuddin, 1988: 16). 
Dengan bertambah banyaknya perkebunan, maka perantau-perantau dari Mandailing bertambah banyak pula yang bermigrasi di Medan dan sekitarnya. Masyarakat Mandailing pada umumnya berpendidikan relatif tinggi dibanding masyarakat Melayu Sumatera Timur. Oleh karena itu tidak mengherankan bila mereka mendapat posisi yang lebih baik di masyarakat dengan pekerjaan sebagai guru agama, Qadi atau pegawai. Beberapa di antara mereka bahkan menjadi saudagar kelas menengah.

Dengan motivasi yang kuat Syekh Mohammad Ya'kub berusaha merealisasi keinginan tersebut, beliau berinisiatif untuk mengajak masyarakat Mandailing mengumpulkan dana untuk pembangunan maktab. Masalah pendanaan tidak menjadi sebuah kendala yang berarti, sebab di antara mereka itu terdapat pedagangan yang berada dan sukses. Akan tetapi, kendala yang muncul kemudian adalah dalam mencari tempat untuk dibuat sebuah maktab, apalagi lagi yang diinginkan untuk membantu maktab tersebut adalah di sekitar Kesawan yang terletak di jantung kota Medan.

Namun dengan adanya hubungan baik dengan masyarakat Melayu, akhirnya mereka mendapat sebidang tanah dari Datuk Haji Mohammad Ali, seorang hartawan Melayu yang banyak memiliki tanah di kampung Kesawan. Beliau memberikan sebidang tanah sebagai wakaf, dan sebagai nazhir (pengurus) tanah yang diwakafkannya itu ditunjukkanya Haji Ibrahim, penghulu kampung Kesawan dan juga Syekh Mohammad Ya'cub. Dalam surat wakafnya dicantumkan bahwa di tanah tersebut akan didirikan sebuah rumah wakaf tempat belajar ilmu agama Islam dan bila salah seorang dari nazhir tersebut meninggal, maka kedudukannya diserahkan kepada ahli warisnya.

Gedung maktab ini dibangun gotong royong oleh masyarakat Tapanuli (Mandailing) yang menetap di Medan, dan selesai tepat pada tanggal 8 Maret 1918 dan kemudian diresmikan pada tanggal 19 Maret 1918. Bangunan maktab ini terdiri dari empat ruangan belajar dan satu ruangan administrasi. Peralatan gedung seperti meja, bangku dan lainya di peroleh dari sumbangan Mayor Tjong A Fie seorang dermawan Cina. Bantuan dari Mayor Tjong A Fie ini menunjukkan bahwa masyarakat Tapanuli di Medan mempunyai hubungnan baik dengan masyarakat Cina, antara lain hubungan dagang yang menyebabkan mereka saling berkepentingan. Penyebutan Mayor ini bukan merupakan kepangkatan dalam militer, tetapi karena beliua orang yang palang terpandang dalam etnisnya.

Maktab ini kemudian dinamakan dengan Maktab Islamiyah Tapanuli (MIT) yang dipimpin oleh Abdurrahman Syihab (putra seorang perantau Madailing, Haji Syihabuddin, qadhi Sultan Serdang), dan kemudian pengajian yang awalnya diadakan di rumah Syekh Ja'far dipindahkan ke maktab ini. MIT ketika termasuk lembaga pendidikan modern, sebab sudah menggunakan sistem kelas, namun tetap mempunyai ciri-ciri tradisional, sebab masih menggunakan sistem hafalan.

Al-Jam'iyatul Washliyah sendiri resmi berdiri pada hari minggu tanggal 30 November 1930 Masehi atau tepatnya 9 Rajab 1349 Hijrah di Medan. Sehingga setiap tanggal 30 November diresmikan dan ditetapkan sebagai hari lahirnya "al-Jam'iyatul Washliyah". Susunan yang pertama terdiri dari: Ketua H. Ismail Banda, Penulis (sekretaris) H. Muhammad Arsyad Tahlib Lubis, Bendahara H. Muhammad Ya'kub, Pembantu-pembantu H. Syamsuddin, Abdul Malik, Abdul Aziz Efendy dan Muhammad Nurdin. Kepada mereka diserahkan untuk segera menetapkan Anggaran dasar al-Washliyah (Syahrul AR el-Hadidhy, 2005: 2-4).

Ide didirikannya organisasi ini berawal dari perluasan sebuah perhimpunan pelajar yang ada di MIT yang merupakan satu-satunya lembaga pendidikan agama 
yang ada di kota Medan, yang ide awal pembentukannya dilakukan oleh pelajar-pelajar kelas tinggi MIT yang membentuk kelompok diskusi pada tahun 1928 yang mereka namakan dengan "Debating Club" yang tujuannya adalah untuk mendiskusikan pelajaran-pelajaran yang mereka pelajari di maktab.Perkumpulan atau kelompok diskusi pelajar seperti ini adalah hal yang sudah lumrah dan banyak dibentuk di kalangan pelajar-pelajar sekolah umum. Di Medan sendiri terdapat kumpulan pemuda Jong Islamieten Bond (JIB) cabang Medan yang didirikan oleh pelajar-palajar Indonesia yang belajar di sekolah Belanda pada tahun 1926. akan tetapi pelajaran MIT tidak tergabung di dalam keanggotaanya, karena mereka belum mampu berkomunikasi dalam bahasa Belanda, bahasa yang di pergunakan JIB. Mereka membentuk sebuah perkumpulan sendiri dengan nama Debating Club. Pemberian nama ini mengandung arti bahwa mereke berkeinginan berdiri sejajar dengan rekanrekan pelajar Islam yang belajar di sekolah Belanda (Chalijah Hasanuddin, 1988: 3435). Setelah beberapa pertemuan dengan para ulama, dalam sebuah pertemuan di rumah Muhammad Joenoes pada 26 Oktober 1930, para pelajar dan ulama mengeluarkan keputusan untuk mendirikan sebuah organisasi yang bernama $\mathrm{Al}$ Djam'iatoel al-Washlijah.Nama ini diberikan oleh Syaikh HM Joenoes yang berarti perhimpunan yang memperhubungkan dan mempertalikan. Menurut analisis Ridwan Lubis, nama tersebut mempunyai dua makna dua dimensi. Pertama, memperhubungkan antara manusia dengan khaliqnya, Kedua memperhubungkan sesame manusia termasuk untuk mempertemukan dan mempersatukan dua kelompok yang berbeda, yakni Kelompok Tua dan Kelompok Muda (Lebih lanut lihat dalam buku Peringatan 30 Tabun Mubammadiyah di Sumatera Timur: 34-38).

Adapun yang menjadi latar belakang utama dari berdirinya Al Washliyah (Syahrul AR el-Hadidhy, 2005: 2-4) paling tidak ketika itu di dorong dengan ada dua hal:

1) Semangat Nasionalisme

Al Washliyah itu berdiri pada masa penjajahan Belanda. Pada masa itu semangat ingin bersatu mulai timbul di tengah-tengah masyarakat. Di tanah air ketika itu telah lahir Budi Utomo, Syarikat Islam, Muhammadiyah, Nahdhatul Ulama dan sederetan organisasi besar lainnya. Demikian pula persatuan umat Islam di Sumatera Timur ketika itu begitu kental, hal ini ditandai banyaknya Pesantren, Rumah Suluk, Pengajian dan Kelompok (perserikatan) umat Islam timbul di mana-mana.

2) Latar Belakang Sosio Keagamaan dengan Munculnya Masalah Khilafiyah di Tengah Masyarakat

Memasuki abad ke 19 telah terjadi pertentangan dikalangan umat Islam khususnya di Sumatera Barat dan Sumatera Utara yaitu antara Kaum Tua (Islam Tradisional) yang mengamalkan ibadahnya menurut kebiasaankebiasaan kaum lama dengan paham baru yang dibawa oleh pelajar-pelajar Islam dari Timur Tengah dan India yaitu kaum Muda Moderat. Paham ini banyak melakukan pembaharuan dan menyatakan ibadah Kaum Tua adalah bid'ah.

Belum lagi ditambah kemultietnisan masyarakat di Sumatera Uatara ketika dengan banyaknya pendatang yang kemudian berakibat munculnya, berbagai pertentangan dalam berbagai hal. Salah satu diantaranya adalah pertentangan pemahaman keagamaan.

Persoalan yang sering terjadi biasanya terhadap masalah furu'iyah dan banyak pada masalah prinsipil, namun karena ada faktor lain yaitu faktor politik "adu domba" penjajah Belanda saat itu sangat 
mempengaruhi dan mempertajam sumber konflik sebagai perbedaan pandangan dan termasuk persoalan kbilafiyah di antara umat Islam. Dalam kenyataannya perbedaan masalah furu'iyyah di antara kedua golongan sudah diambang bahaya, kelompok tua merasa berbeda lain dengan kelompok kaum muda dalam hal ini terwakili oleh Muhammadiyah, bahkan diantara saudara kandung ada yang terpisah persaudaraannya karena aliran yang berbeda.

Faktor sosio keagamaan dengan banyaknya bermunculan permasalahan khilafiyan ini, kemudian menjadi faktor utama pembentukan Dewan Fatwa Al Washliyah, sebagai lembaga khusus dalam keorganisasian Al Washliyah yang bertujuan untuk menyelesaikan persoalan hukum yang khususnya terjadi pada warga $\mathrm{Al}$ Washliyah khususnya dan masyarakat Islam di Sumatera Utara pada umumnya.

Pada awal pembentukkannya Dewan Fatwa ini diberi nama dengan Majelis Fatwa yang berdiri tepat pada 10 Desember 1933, tiga tahun setelah Al Washliyah resmi berdiri. Lembaga Dewan Fatwa ini dibentuk oleh kepengurusan Al Washliyah yang pertama. Kepengurusan pertama ini menyusun 7 (tujuh) bagian Majelis yang akan melaksanakan program kerja organisasi, yang salah satu di antaranya adalah Majelis Fatwa.Duduk sebagai pengurus pertama adalah Syekh Mahmud Yunus (Penasehat) Ismail Banda (Ketua), Abdurrahman Syihab (Wakil Ketua) dan Mhd. Arsyad Thalib Lubis (Sekretaris), dan beberapa orang pembantu. Kepengurusun ini menyusun tujuh program kerja yaitu: (1). Tabligh (Ceramah Agama), (2). Tarbiyah (Pengajaran), (3). Pustaka/Penerbitan, (4). Fatwa, (5). Penyiaran, (6). Urusan Anggota, dan (7). Tolong Menolong. (Chalijah Hasanuddin, 35-36).

2. Ideologi $\mathrm{Al}$ - Jam'iyatul Washliyah

Memang, dalam bidang doktrin keagamaan terdapat perbedaan yang sangat jauh dengan Muhammadiyah, karena Al Washliyah berasaskan Islam dalam iktihad serta berpegang teguh dengan mazhab Syafi'I dan dalam I'tiqad Ahlu Al-Sunnah wa Al-Jama'ah. Hal ini sesuai dengan Anggaran Dasar Al-Washliyah BAB II Pasal 2 tentang Asas dan Akidah. (Lihat di dalam buku Bunga Rampai Al-jam'iyatul Washliyah, 2010: 27). Maksudnya adalah bahwa setiap gerak, cita-cita, dan usah-usaha perhimpunan ini haruslah sesuai tuntunan dan ajaran Islam. Sehingga jika dibandingkan dengan organisasi Islam lainnya, apalagi dengan Muhammadiyah yang notabene adalah organisasi yang dianggap berseberangan dengan $\mathrm{Al}$ Washliyah, maka Al Washliyah sendiri adalah termasuk organisasi tradisional yang bisa mewakili kaum tua, sebab jika dilihat dari awal munculnya Al Washliyah adalah karena begitu kuatnya pengaruh Muhammadiyah yang mengklaim dirinya sebagai organisasi tajdid. Identitas tajdid ini semakin menonjol setelah mukhtamar Muhammadiyah ke-42 di Yokyakarta tahun 1960, dalam salah satu putusannya berhubungan dengan identitas Muhammadiyah dengan menetapkan Ketua Bidang Tajdid, yang dalam struktur kepengurusan sebelumnya tidak pernah ada. Inilah yang kemudian menjadikan dasar kuat untuk menyatakan Muhammadiyah sebagai gerakan tajdid. Walaupun masih terjadi perbedaan pendapat tentang rumusan yang tepat dari tajdid itu, sampai akhirnya pada tahun 1989 pada mukhtamar ke-22 di Malang dirumuskan defenisi yang resmi bagi Muhammadiyah (Lihat dalam Fathurrahman Djamil, 1995: 57-59).

Latar belakang dari didirikannya Muhammadiyah dapat dicari dari adanya perselisihan mengenai taqlid dan persoalan yang berkaitan dengannya antara kaum muda dan tua di Medan. Perselisihan ini masih dipertajam oleh perbedaan antara 
orang Padang dan Batak, sehingga kalau perselisihan itu dianggap sebagai kriteria untuk menilai Al Washliyah, maka Al Washliyah sebagaimana yang dikutip oleh Steenbrink dapat disebut sangat ortodoks dengan ejekan konservatif (Karel A. SteenBrink, 1986: 78). Meskipun Steenbrink sendiri menyatakan bahwa tidak cukup objektif kalau organisasi Al Washliyah hanya dilihat dari beberapa faktor yang negatif dan ekstrem saja, yaitu menolak cita-cita dari kelompok lain, sebab organisasi ini juga bisa dikatakan modern, ini karena cikal bakal berdirinya Al Washliyah adalah daripara pelajar MIT yang merupakan sekolah Islam modern di Medan saat itu.

Namun dalam aspek pemahaman keagamaan Steenbrink menjelaskan bahwa cap "tradisional", ia mencontohkan bahwa dari kumpulan fatwa yang diterbitkan oleh Al Washliyah, yang pada umumnya berasal dari fatwa Arsyad Thalib Lubis, yang awalnya adalah brosur-brosur kecil. Persoalan yang dibicarakan hampir sama dengan isi karya Sirajuddin Abbas dalam bukunya 40 Masalah Agama. Pendapat yang sama juga dinyatakan oleh Taufik Abdullah (1987: 29) yang mengkategorikan pola pemikiran ulama Al Washliyah ke dalam kelompok tradisional. Namun menurut Steenbrink cap "reformis" juga bisa ditujukan kepada Al Washliyah, hal ini dibuktikan untuk mengirim mahasiswa ke Cairo serta usaha mendirikan sekolah umum, yang mengikuti model gubernemen (Karel A. SteenBrink, 1986: 79).

Dalam bidang keagamaan sesuai dengan fungsi yang diembannya, terkait persoalan hukum yang mereka keluarkan. Pendapat hukum yang mereka keluarkan hanyalah sebatas fatwa, yang dirujuk kepada pendapat ulama klasik. Di kalangan ulama Al Washliyah menganggap bahwa hanya para ulama terdahulu saja yang mampu menetapkan hukum karena: "Tidak semua orang mempunjai kesanggupan mengeluarkan bukum dengan sendirinja dari dalam Quran dan Hadis karena untuk melaksakan pekerdjaan tersebut harus memenubi berbagai sjarat. Harus mengerti benar bahasa Arab mempunyai pelengkapan tentang ilmu-ilmu jang dibadjatkan untuk memahamkan Quran dan Hadis dan berbagai sjarat lain yang diterangkan dalam kitab Ushul fiqih (Lihat di dalam Buku Peringatan 30 Tabun Mubammadiyah di Sumatera Timur: 351).

Al Washliyah melalui Dewan fatwanya berprinsip bahwa mereka tidak menolak ijtihad, tetapi karena mereka menganggap diri mereka belum memiliki kemampuan dan kapasitas intelektual yang memadai untuk melakukan ijtihad, sehingga mereka tidak merasa diri mereka sebagai mujtahid tetapi adalah mengambil sebuah keputusan fatwa mereka tetap berpedoman dengan AD/ART yaitu dengan berpedoman dan mengikuti (taqlid) dengan pendapat yang dinyatakan oleh mazhab Syafi'i.

Namun sebaliknya jika dibandingkan dengan aliran pembaharuan yang lainnya seperti Muhammadiyah dan Persis, mereka hanya mengakui Al Qur'an dan Hadis sebagai sumber hukum dan menolak bertaqlid. Menurut mereka taqlid ini akan menyebabkan manusia itu tidak mampu menggunakan akal sehingga timbul paham yang jumud (beku). Paham ini mengakibatkan manusia tidak mampu mengikuti perkembangan zaman karena menggangap pintu ijtihad telah tertutup. Di samping itu, Persis juga mengakui ittiba' yaitu mengikuti satu pendapat dengan mengetahui dalilnya dari Al Qur'an dan Hadis. Menurut Deliar Noer, pengakuan tentang ijtihad dan kembali pada Al Qur'an dan Hadis sebagai sumber hukum seperti ini, tidak muncul secara tiba-tiba, melainkan berangsur-angsur, terkadang disebabkan oleh tantangan yang datang dari golongan tradisi. Ia memberi contoh Minangkabau, di sini taqlid diarahkan kepada golongan adat, sedangkan imam-imam pendiri mazhab tetap dihormati sebagai mujtahid (Deliar Noer, 1982: 64-65). 
Ini sangat berbeda jauh dengan $\mathrm{Al}$ Washliyah yang secara jelas bertaqlidnya kepada mazhab Syafi'i, yang penegasan ini kemudian dicantumkan di dalam Anggaran Dasar Al Washliyah. Sebagaimana terlihat dalam Anggaran Dasar pada Pasal 2, yakni:

"Al Washliyah sebagai organisasi kemasyarakatan yang berakidah Islam, dan bukum fikih bermazhab Syafi'i dan dalam I'tikad Ablu Sunnab Wal Jama'ab"(Lihat Anggaran Dasar dan Anggaran Rumah Tangga Al-jam'iyatul Washliyah, 1987: 4).

Berpaham dengan mazhab Syafi'i dimaksudkan untuk memperkuat persatuan dan kesatuan dengan menghimpun orang-orang yang sepaham untuk berjuang membangun sesuatu yang menjadi tuntutan agama demi kepentingan umat Islam dan warga Al Washliyah khususnya.

Penyebutan bermazhab Syafi'i bukan berarti Al Washliyah tidak menghormati pendapat mazhab lain. Karena Al Washliyah menyadari bahwa hukum adalah hasil ijtihad yang bersifat Sanni yang tidak mempunyai kebenaran absolut dan Al Washliyah bersikap tasamub (toleran) terhadap segala perbedaan pendapat dan paham. Perbedaan merupakan hal yang wajar dan tidak perlu membawa perpecahan umat. Penyebutan bermazhab Syafi'i di dalam AD supaya menunjukkan tempat berpijak dalam fikih sekaligus referensi hukum bagi Al Washliyah dalam menghadapi persoalan hukum yang timbul (Lihat di dalam Nukman Sulaiman, 1956: 18-20).

3. Amal Usaha Al - Jam'iyatul Washliyah

Untuk mengukuhkan asas dan mencapai tujuan Al Washliyah haruslah ada ikhtiar dan usaha yang digerakkan, antara lain:

1) Mengadakan, memperbaiki, dan memperbuat hubungan persaudaraan umat Islam dalam dan luar negeri dan berbuat serta berlaku adil terhadap sesama manusia.

2) Membangun perguruan-perguruan dan mengatur kesempurnaan pengajaran pendidikan dan kebudayaan. Pengajaran, pendidikan, dan kebudayaan adalah merupakan factor yang sanagat menentukan bagi nilai-nilai pribadi dan masayarakat sepanjang zaman. Dia akan tetap mengalami perkembangan, satu waktu ia membentuk zaman dan di lain waktu ia dibentuk zaman.

3) Menyantuni fakir miskin dan memelihara serta mendidik anak yatim piatu dan anak miskin. Anak yatim piatu fakir miskin adalah merupakan penyakit pribadi sebagai anggota masyarakat yang tetap dijumpai sepanjang zaman. Penyakit ini dapat diperbaiki atau pun dikurangi dengan penyantunan yang diberikan secara efektif, berencana, dan berprogram.

4) Mengusahakan berlakunya hukum-hukum Islam.

5) Mempersiapkan umat Islam dalam menegakkan dan mempertahankan kebenaran dan keadilan. (Lihat di dalam buku Al Rasyidin,dkk, 2011: 32-36).

\section{PENUTUP}

Sejarah adalah sebuah dialog intelektual antara manusia dengan pengalaman kolektifnya pada masa lampau. Bahwa pengalaman itu kita harapkan mampu menangkap iktibar (pelajaran moral) untuk dijadikan acuan dan pedoman masa kini, dalam rangka mempersiapkan masa depan yang lebih baik dan lebih cerah.

Sekalipun manusia tidak punya kemampuan untuk meramalkan masa depan secara pasti, namun Al Qur'an mengajarkan agar kita mempersiapkan masa depan itu secerdas dan secermat mungkin. "Hai orang-orang yang beriman, bertakwalah kepada Allah dan hendaklah setiap diri 
memperhatikan apa yang Telah diperbuatnya untuk hari esok (akbirat); dan bertakwalah kepada Allah, Sesunggubnya Allah Maha mengetahui apa yang kamu kerjakan” (QS. Al Hasyar: 18).

Dari pengalaman kolektif masa lampau, diharapkan akan dapat melihat benang merah pemihakan Allah Swt. kepada perilaku sejarah tertentu, sebab dalam Al Qur'an dijelaskan bahwa Allah Swt. tidak bersikap netral, akan tetapi Allah Swt. sepenuhnya berpihak kepada mereka yang telah berhasil mengembangkan nilai-nilai taqwa dan ihsan (QS. An Nahl: 128). Muhammadiyah dan Al Washliyah merupakan fakta sejarah berdirinya dua organisasi besar di Sumtera Utara yang merupakan gerakan bersama dalam perubahan gerakan Islam yang lebih maju, serta menentang kemungkaran dari kelompok luar yakni penjajah, yang menjadikan sebuah aksi yang salah satu alasan negeri ini terbebas dari penjajahan. Namun, dibalik itu, sejarah juga membuktikan bahwa dua organisasi ini yang sama-sama memberantas penjajahan ini memiliki perbedaan paham dalam hal ibadah yang akhirnya mempengaruhi sosial dan kultural di Sumatera Utara.

Muhammadiyah yang disebut Kaum Muda menjadi sebuah gerakan tajdid (pembaharuan) yang membuka lembaran baru dalam reformasi gerakan berpikir Kaum Tua pada saat itu. Kaum Tua pada saat itu yakin bahwa praktik-praktik ibadah di luar hukum-hukum Islam-seperti tepung tawar, dan ibadah-ibadah kejawen lainnya-akan lenyap dengan sendirinya setelah umat Islam mengetahui kewajiban-kewajiban religius dan hukum agama, namun ditangan Kaum Muda hal ini tidak dapat diberikan tolerir. Kaum Muda menganggap toleransi Kaum Tua tersebut melemahkan Islam. Oleh sebab itu praktik-praktik ibadah tersebut harus diluruskan agar Islam kembali suci dari animisme, dinamisme, kejawen, hindu, budha, dan adat, yang semuanya itu telah mengotori kemurnian Islam di Indonesia dan khususnya di Sumatera Utara. Di Sumatera Utara, Al Washliyah pun hadir dalam menjembatani perselisihan antara Kaum Muda dan Kaum Tua.

Membandingkan al-Washliyah dengan Muhammadiyah bukanlah dimaksudkan untuk melihat sisi doktrin keagamaan yang dianut keduanya, bukan berupaya justifikasi kebenaran dari salah satu organisasi. Sebab Muhamadiyah itu dikategorikan sebagai kelompok yang mewakili kaum Muda yang lahir karena menolak ajaran kaum Tua. Sedangkan al-Washliyah di sisi lain muncul dalam rangka menolak klaim bid'ah kaum muda terhadap kaum Tua, al-Washliyah dalam hal ini mewakili kaum tua yang berupaya membenarkan ajaran kaum Tua berdasarkan dalil-dalil syar'a, dan hal ini sesuai dengan makna Al-Djam'iatoel al-Washlijah yakni menghubungkan sesama manusia termasuk untuk mempertemukan dan mempersatukan dua kelompok yang berbeda ini.

Terkait hal tersebut di atas dalam menilai suatu peristiwa sejarah, tidak dapat digunakan ukuran-ukuran subjektif semata-mata, tetapi wahyu perlu dijadikan pedoman dalam memberikan pertimbangan moral terhadap episode sejarah di atas. Sebagai penikmat dan sekaligus pelaku sejarah, kita dapat menilai dan menyelidiki dengan menuntut bukti, fakta bukan fiktif, bila sejarah yang bukan faktual, maka gugurlah nilai sejarahnya. Oleh sebab itu "keegoisan" dalam menilai sejarah jangan didahulukan, tetapi sesuaikan dengan keyakinan (wahyu) dalam menilainya.

\section{REFERENSI}

“Majalah Soeara Moehammadijab” Nomor 4 Tahun 1939.

30 Tahun Muhammadijah Daerah Sumatera Timur. Medan: Panitian Besar Muhammadiyah, 19271957.

Abdullah, Taufik. Islam dan Masyarakat, Cet. I. Jakarta: LP3ES, 1987.

Al Rasyidin,dkk, Al Jami'yatul Washliyah. Medan: CAS \& Perdana Publishing, 2011.

Anggaran Dasar dan Anggaran Rumah Tangga Al-jam'iyatul Washliyah, Tahun 1987. 
Anshori, M.A, H. Ari. 'Ideologi Mubammadiyah dan Reaktualisasi Islam yang Berkemajuan dalam Dinamika Peradaban Kontemporer”. 2011.

Batubara, Ismed. Ja'far, ed. Bunga Rampai Al-Jam'iyatul Washliyah. Banda Aceh: AUP, 2010.

Bolan, The Struggle.

Djamil, Fathurrahman. Metode Ijtihad Majlis tarïh Mubammadiyah, cet. I. Jakarta: Logos, 1995.

Effendy, Muhadjir. Menggugat Pendidikan Muhammadiyah. Malang: Penerbit UMM-Press, 2005.

el-Hadidhy, Syahrul AR. et.al.Pendidikan Ke Al-Washliyahan. Medan, MPK Al-Jam'iyatul Washliyah, 2005.

Hasanuddin, Chalijah. Al-Jam'iyatul Washliyah Api Dalam Sekam. Bandung: Pustaka, 1988.

Kartodirjo, Sarto. Sejarah Pergerakan Nasional: Dari Kolonialisme Sampai Nasionalisme. Jakarta: Gramedia, 1992.

Muhammadiyah; Pemberdayaan Umat? editor: M.A Fattah Santosa, Maryadi. Surakarta: Muhammadiyah University Press, 2001.

Noer, Deliar. Gerakan Modern Islam, h. 11. Lihat juga Harun Nasution, Pembaharuan Dalam Islam. Jakarta: Bulan Bintang, 1982.

Pasha, Musthafa Kamal dan Ahmad Adaby Darban. Muhammadiyah Sebagai Gerakan Islam-dalam Persepektif Historis dan Ideologis. Yogyakarta: LPPI UMY, 2003.

Pedoman Kehidupan Islami Warga Mubammadiyah; Keputusan Muktamar Muhammadiyah Ke-44 Tanggal 8 s/d 11 Juli Tahun 2000. Jakarta: PIMPINAN PUSAT MUHAMMADIYAH $1421 \mathrm{H} / 2000 \mathrm{M}$.

Pelly, Usman. Urbanisasi dan Adaptasi; Peranan Misi Budaya Minangkabau dan Mandailing. Jakarta: LP3ES.

Pijper. Fragmenta Islamica.

Profil Muhammadiyah Sumatera Utara. Medan: 2005.

Salam, Solichin. Muhammadiyah dan Kebangunan Islam di Indonesia. Jakarta: NV Mega, 1956.

SteenBrink, Karel A. Pesantren Madrasah Sekolah. Jakarta: LP3ES,1986.

Sulaiman, Nukman. Peringatan 1/4 Abad Al-Jam'iyatul Washliyah. Medan: PB Al-Jam'iyatul Washliyah, 1956.

Surya Negara, Ahmad Mansur. Menemukan Sejarah; Wacana Pergerakan Islam di Indonesia. Bandung: Mizan, 1996. 